\title{
Estimate the Optimal Proportional Reinsurance Method in Property Insurance
}

\author{
Mohamed T. EL-bolkiny \\ Professor of Actuarial sciences and \\ Insurance \\ Department of Applied Statistics and \\ Insurance \\ Faculty of \\ Commerce, Mansoura University, Egypt \\ Jamaal A. Wasif \\ Professor of Insurance and Statistics \\ Department of Applied Statistics and \\ Insurance \\ Faculty of \\ Commerce, Mansoura University, Egypt
}

Ronald W. Spahr

Professor and Former Chair

Department of Finance, Insurance and Real Estate

Fogelman College of Business \& Economics University of Memphis, USA

\section{Mark A. Sunderman}

Professor and Morris Fogelman Chair in Real Estate Department of Finance, Insurance and Real Estate

Fogelman College of Business \& Economics University of Memphis, USA

Mohamed M. Elmadawye

Assistant Lecture, Department of Statistics and Insurance

Faculty of Commerce - Zagazig University, Egypt

\begin{abstract}
:
The study analysis properties of types of proportional reinsurance cover (such as quota share reinsurance, variable quota share reinsurance, surplus reinsurance and quota share with surplus reinsurance). Also, assessed the impact of proportional reinsurance on the Egyptian insurance Market. The study used risk measures, the Value-at-Risk (VaR) and the Conditional-TailExpectation (CTE) of aggregate claims distributions, these risk measures have been used to the determination of optimal reinsurance. This study Estimated optimal reinsurance by maximize the Return on Risk Adjusted Capital of the retained risk (RORAC).
\end{abstract}


Keywords: Proportional reinsurance, Quota-Share reinsurance, Variable Quota-Share reinsurance, Surplus reinsurance, optimal reinsurance, VaR, CTE, RORAC.

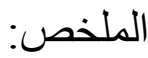

في هذا البحث تم دراسة عدة طرق مختلفة لإعادة التأمين النسبي (إعادة تأمين

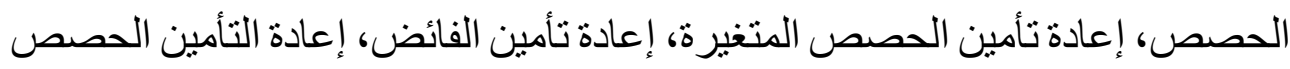

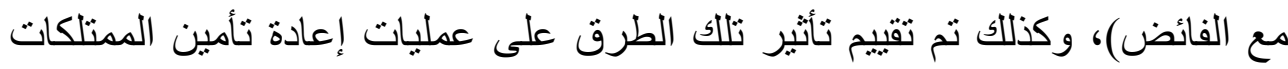
بالتطبيق علي سوق التأمين المصري. وقد استخدمت الدراسة مقاييس الخطر التالية Conditional tail expectation (CTE) ، Value at risk (VaR)

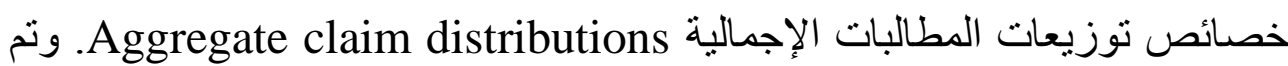
تحديد إعادة التأمين المنلي من خلال استخدام مقياس تعظيم العائد علي رأس المال Return on Risk Adjusted Capital (RORAC) طريقة إعادة التأمين المثلي هي طريقة الحصص بحد احتفاظ مقداره • ؛ \%، حيث انها

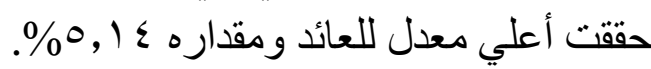

\section{1- Introduction}

The reinsurance has an important role in the insurance industry, where primary insurers may distribute some or all their underwriting risks to reinsurance companies. the optimal size in reinsurance property in the Egyptian insurance companies is one of the most important problems that hinder the optimal utilization of the proceeds of the insurance business.

As the annual Insurance Market Report of the Egyptian Financial Supervisory Authority ((EFSA), 2017), all companies in the market have extensive proportional reinsurance programmes, so the study will analyze properties of types of proportional reinsurance.

The study will use the actuarial models of risk theory to estimate the optimal proportional reinsurance methods. The study 
will use of risk measures of Value-at-Risk ( $\mathrm{VaR})$ and ConditionalTail-Expectation (CTE) of aggregate claims distributions and it will seek to Estimate optimal reinsurance by maximize the Return on Risk Adjusted Capital of the retained risk (RORAC).

There are many studies discussed the optimal reinsurance problem from different assumptions and by using different measures to compute the direct insurance risk. Moreover, the risk measures are becoming very important in actuarial sciences, Finance and Insurance. In 1940, Bruno de Finetti introduced the first study in the optimal reinsurance problem. It employed reinsurance principles to determine the optimal retention level for non-life insurance under assumption of minimization the variance of the direct insurance profit. The study presented how optimal levels should be calculated for quota-share reinsurance and excess-of-loss reinsurance. The results he obtained points that the retention level is relative to the direct insurance loading factor and inversely relative to the variance of the risk.

Another important paper designed by Borch (1960) discussed the stop loss reinsurance when minimize the variance of the retained loss if premiums calculated using the expected value principle. As an improvement on Borch (1960), the study of Arrow (1963) extended the work of the expected value principle and found that the stop loss reinsurance increases the expected utility of the wealth of the direct insurance.

Waters $(1979,1983)$ discussed the optimal levels of the Excess-of-Loss reinsurance using the ruin probability. The study assumption that the aggregate claims as a compound Poisson process. The study presented the insolvency constant of the direct insurance and the function of Excess-of-Loss reinsurance retention 
level. The study found the non-proportional case cannot be possible to generalize the distribution of annual claims.

Lampaert and Walhin (2005) discussed the optimality of the proportional reinsurance methods. They studied a numerical example which found that quota-share was suboptimal method in all types of proportional reinsurance methods. Quota-share reinsurance would be interest to the reinsurance company when the reinsurer's safety loading is smaller than safety loading of the direct insurance. Also, the surplus reinsurance with one single line is optimal method than surplus reinsurance with a table of lines depended on the inverse rate or the inverse frequency method. They also derived, using the DeFinetti's measure and Return on Risk-Adjusted Capital (RORAC) that the table of lines method was the optimality reinsurance of the proportional reinsurance programmes.

As an improvement on Lampaert and Walhin (2005), the study of Glineur and Walhin (2006), the authors extended DeFinetti's retention problem for proportional reinsurance using the convex optimize method. They studied a numerical example which found that variable quota-share reinsurance or surplus reinsurance were suboptimal reinsurance methods.

Dickson and Waters (2006) considered the problem of minimizing the ruin probability for the retention levels by a dynamic optimal reinsurance strategy. In this paper, the authors derived a formula of the optimality of the joint survival probability using the Bellman optimality principle.

Cai and Tan (2007) discussed the optimal retention in nonProportional reinsurance stop-of-loss reinsurance under reducing the Value-at-Risk (VaR) and the Conditional Tail Expectation 
(CTE). In this study, the authors presented the optimal retention using the loss distribution of the direct insurance company and the safety loading coefficient of the reinsurance company.

Cai et al. (2008) introduced the conditions for optimal reinsurance designs optimization problem by minimizes the Value-at-Risk (VaR) or Conditional Tail Expectation (CTE) of the total cost of the reinsurer deepened on risk measures with confidence level $(1-\alpha)$, safety loading $(\rho)$ for the reinsurance company premium, and the expectation premium principle for setting the reinsurance premium. The results of study showed that a stop-loss reinsurance is optimal in some cases, and in other cases, a quota-share reinsurance or a change-loss reinsurance is optimal.

Balbás et al. (2009, 2015) Balbás et al. (2009) employed modern risk measures to determine the optimal reinsurance problem under the assumption that the reinsurer's premium fixed as a convex function. The study presented risk measures like as expectation, deviation, coherent and convex measures, which used to analyze the optimal reinsurance problem. the paper showed that quota share reinsurance type was suboptimal rather other types under concrete risk measures with focus on the conditional of Value at Risk (VaR).

Hurlimann (2010) introduced the proportional reinsurance types (quota share, surplus) and non-proportional reinsurance types (excess of loss, stop loss). The study considered the problem of the optimal reinsurance method under assumption of expected value of the premiums using de Finetti and RORAC methods. The results of numerical examples of the study showed that the nonproportional reinsurance types were more efficient than the proportional reinsurance types. in addition, the study showed that 
the excess-of-loss reinsurance type was optimal than stop-loss type.

Balbás et al. (2015) discussed the optimal reinsurance problem for the direct insurance company and reinsurance company when facing risk and uncertainty, the levels of uncertainty of the direct insurance company and reinsurance company do not have to be identical and the decision variable is not the retained (or ceded) risk, but its sensitivity (mathematical derivative) with respect to the total claims. the study presented the principle contributions appear to the optimal reinsurance problem conditions are given in a very general setting. moreover, the optimal contract was sensitive between the retained risk and the total claims and the optimal reinsurance problem is equivalent to other linear programming problem.

Yuen et al. (2015) consider the optimal proportional reinsurance strategy in a risk model with multiple dependent classes of insurance business, which extends the work of Liang and Yuen (2014). they determined the optimal reinsurance strategies under the expected value premium principle are very different from those under the variance premium principle in the diffusion risk model. They depend on the safety loading, time, interest rate, and on the claim size distributions and the counting processes.

Chi et al. (2017) presented the optimal reinsurance problem from the perspective of an insurer with minimize the risk adjusted value for the liability of the direct insurance company using risk measures as the Value-at-Risk ( $\mathrm{VaR})$ or Conditional Value-atRisk (CVaR). The study assumed that the direct insurance company and reinsurance company are committed to pay more as a way of reducing ex-post moral hazard. The study showed that 
optimal reinsurance policies are piece wise linear under both VaR and CVaR risk measures. While the structures of optimal reinsurance solutions are the same for both risk measures, it also formally shows that there are some significant differences, particularly on the managing tail risk.

Karageyik and Sahin (2017) presented the optimal retention levels with survival probability, expected profit, variance and expected shortfall for the direct insurance company risk. The study assumption that the aggregate claim amounts were follow a compound Poisson distributions and the individual claim amounts were follow exponential distribution. The authors determined the optimal retention levels depending on two approaches: the first was maximization the expected profit and the survival probability, the second minimization the variance and the expected shortfall of the direct insurance company risk. Also, the study analyzed the optimal retention levels under the expected value and standard deviation premium principles.

\section{2- The problem of study}

the problem of this study is the decision regarding the efficient optimal retention levels or optimal reinsurance method for an insurer is often complex and subject to judgment, it can change over time as business objectives and conditions vary. So, the study will use the actuarial models of risk theory to estimate the optimal proportional reinsurance methods, then the optimal of retention levels.

\section{3- Research hypothesis}

- The proportional reinsurance has a positive effect on the survival of the direct insurance companies. 
- The optimal reinsurance methods and the optimal retention levels has a positive impact in minimization the probability of ruin of the direct insurance company.

\section{4- The study objectives}

- The main objective of this paper is to develop theoretically sound and yet practical solution in the quest for optimal reinsurance designs.

- Evaluate the impact of the proportional reinsurance method on the survival of the direct insurance companies.

- Estimate the optimal reinsurance method and the optimal retention levels which maximize the return on risk adjusted capital of the retained risk using the proportional reinsurance methods.

- Evaluate the role of reinsurance in minimizing the probability of ultimate ruin of the direct insurance company.

\section{5- Research Methodology}

\section{5-1 Proportional Reinsurance}

The proportional reinsurance forms (or "Pro rata") sharing all losses and premiums between the direct insurance and the reinsurer in a fixed share. The types of proportional reinsurance are:

Standard Quota Share, the same percentage of retention of liability applies to all polices covered by the treaty until the terms of treaty are changed (Reinarz et al., 1990). In quota-share reinsurance, everything is determined by fixed retention proportion $q, 0<q<1$. Then, all claims divided using proportion $q$ as follows:

$$
S^{I}=(1-q) . S, \quad S^{R}=q \cdot S
$$


Variable Quota Share, the percentage of cession varies automatically by risk based upon the size of a risk or its class (Reinarz et al., 1990). The risk divided between insurer and reinsurer is given by:

$$
S^{I}=\sum_{j=1}^{m}(1-q) \cdot S_{j}, \quad S^{R}=q_{j} \cdot S_{j}
$$

Where:

$$
S_{j}=\sum_{i=1}^{N_{j}} X_{j i,} \quad j=1,2, \ldots \ldots, m, \quad S=\sum_{j=1}^{m} S_{j}
$$

Surplus, the cession from the direct insurance to the reinsurer is a function of both the sum insured $(S I)$ and a quantity called the line (or retention), it determined by the direct insurance company. The line (M) is the maximum amount that the direct insurance is willing to pay in case of a loss (for each policy in the portfolio), The retention percentage is always between 0 and 1 (since the line is positive) (Gorge, 2016). The risk is given by:

$S^{I}=\sum_{i=1}^{N}\left(1-\min \left(1, \frac{M}{S I_{i}}\right)\right) \cdot X_{i}, S^{R}=\sum_{i-1}^{N} \min \left(1, \frac{M}{S I_{i}}\right) \cdot X_{i}$

Where:

$S I_{i}$ : the sum insured $\mathrm{SI}_{\mathrm{i}}$ associated to the policy i-th.

$\mathrm{M}$ : the line of retention which is "the maximal amount that the insurer" is willing to pay in case of a loss.

\section{5-2 The model: Collective risk model}

A collective risk model assumed the aggregate loss follow to a compound distribution. Let $N$ be the number of losses in the portofolio polices, and $X_{i}$ be the amount of the $i$ th loss, for $i=1$, $\ldots, N$. Then the aggregate loss $S$ are given by:

$$
S=X_{1}+X_{2} \ldots+X_{n}
$$


The calculation of expectation and variance for $S$ using Compound Poisson distributions are given by (Klugman et al., 2012) (Gray \& Susan, 2012) (El-bolkiny, 2000):

$$
E[S]=\lambda E[X] \quad \text { and } \quad \operatorname{Var}[S]=\lambda E\left[X^{2}\right]
$$

The study assumed that the aggregate claims of an insurance risk portfolio:

$$
\mathrm{S}=\sum_{i=1}^{N} X_{i}
$$

$S^{I}$ : insurer aggregate claims amount (Direct Insurance)

$S^{\mathrm{R}}$ : reinsurer aggregate claims amount

Where:

S: aggregate claim amount distribution

$\mathrm{N}$ : number of claims (frequency distribution)

$X_{i}:$ amount of claim i (severity distribution)

Suppose a portfolio with $\mathrm{N}$ is a random variable of the number of losses and $X_{i}$ be the amount of the $i$ th loss, for $i=$ $1, \ldots, N$. assumed the number and the amount of losses are independent. Then $\mathrm{S}$ is aggregate loss. The $\mathrm{CDF}$ of $S$ is:

$$
\begin{aligned}
F_{S}(x) & =\operatorname{Pr}[S \leq x] \\
& =\sum_{n=0}^{\infty} \operatorname{Pr}[S \leq x \mid N=n] p_{n} \\
& =\sum_{n=0}^{\infty} F_{C}^{* n}(x) p_{n}
\end{aligned}
$$

we need to discrete arithmetic claim amount distribution to estimate the aggregate claim distribution, so we will discuss the methods of discretization the claim amount distribution. (Dutang et. Al.,2008) (Gerber, 1979). 


\section{5-2-1 calculation the aggregate claim amount}

The study will use the convolution method to calculate the aggregate claim amount distribution, Where $F_{X}(x)=\operatorname{Pr}[\mathrm{X} \leq x]$, is the cdf of $X_{1}, \ldots, X_{n}, p_{n}=\operatorname{Pr}[N=n]$ and $F_{X}^{* n}(x)=\operatorname{Pr}\left[X_{1}+\right.$ $\left.\cdots+X_{n} \leq x\right]$ is the $\mathrm{n}$-fold convolution of $F_{X}(\cdot)$. If $X$ is discrete on $0,1,2, \ldots . .$, one has

$$
F_{X}^{* k}(x)=\left\{\begin{array}{lr}
I\{x \geq 0\}, & k=0 \\
F_{X}(x), & k=1 \\
\sum_{y=0}^{x} F_{X}^{*(k-1)}(x-y) f_{c}(y), & k=2,3, \ldots
\end{array}\right.
$$

Where: $I\{A\}=1$ if $A$ is true and $I[A]=0$ otherwise.

\section{5-3 Risk measures}

The study used some risk measures constructed for evaluating economic capital.

\section{5-3-1 Value-at-Risk (VaR)}

The Value at Risk (VaR) is a risk measure used by actuaries to evaluate exposure risk. In other mean, the Value at Risk is the amount of capital required to keep with a high degree of certainty (Klugman et al., 2012). In actuarial literatures it is named as quantile risk measure or quantile premium principle.

We assumed that $X$ is a random variable of the loss with df $F_{X}(\cdot)$, the probability level is $\alpha$ (it is usually taken to be close to 1 ), where $0<\alpha<1$, then the value at Risk with probability level $\alpha$, denoted by $\operatorname{VaR}_{\alpha}(X)$. It given by:

$$
\operatorname{VaR}_{\alpha}(X)=F_{X}^{-1}(\alpha)
$$


If $F_{X}(\cdot)$ is a step function (as when $X$ is not continuous), then $\operatorname{VaR}_{\alpha}(X)$ is:

$$
\operatorname{VaR}_{\alpha}(X)=\inf \left\{x \in[0, \infty) \quad: F_{X}(x) \geq \alpha\right\}
$$

\section{5-3-2 Conditional tail expectation (CTE)}

The Conditional tail expectation (CTE) is one of the most widely used measures of risk in actuarial sciences. It is worth noting that, the Value at Risk (VaR) does not use any information about the loss distribution beyond the cut-off point, so, the "CTE $(\alpha)$ " is the mean of loss which above the VaR at level $\alpha$.

In actuarial studies there are many names of the Conditional tail expectation (CTE) such as, expected shortfall, tail conditional expectation (TCE) and tail value at risk (Tail VaR) (Hardy, 2006).

The Conditional tail expectation (CTE) with probability $(1-\alpha)$, denoted by $\mathrm{CTE}_{\alpha}$, which is:

$$
\operatorname{CTE}_{\alpha}(X)=\mathrm{E}\left[X \mid X>\operatorname{VaR}_{\alpha}(X)\right]
$$

When $X$ is continuous, we have

$$
\mathrm{CTE}_{\alpha}=\mathrm{E}\left[X \mid X>\mathrm{VaR}_{\alpha}\right]=\frac{1}{1-\alpha} \int_{\mathrm{VaR}_{\alpha}}^{\infty} x f_{X}(x) d x
$$

When $X$ is not continuous, we use the following formula

$$
\mathrm{CTE}_{\alpha}=\mathrm{VaR}_{\alpha}+\frac{\mathrm{P}\left(X \geq \mathrm{VaR}_{\alpha}\right)}{1-\alpha} \cdot \mathrm{E}\left(\mathrm{X}-\mathrm{VaR}_{\propto} \mid X>\operatorname{VaR} R_{\propto}\right)
$$

The Conditional tail expectation (CTE) is a coherent risk measure, but Value at Risk is not coherent risk measure (Denuit et al., 2005). 


\section{5-3-3 optimal retention level using RORAC}

The optimal retention level for insurance company in the study is the optimal reinsurance method which determined by the Return on Risk-Adjusted Capital (RORAC). The RORAC maximizes the return on risk adjusted capital of the retained risk and the approach needs the estimation of the business capital depending on the Conditional tail expectation (CTE) at a small predetermined probability (Lampert \& Walhin, 2005).

The approach of Return on Risk-Adjusted Capital (RORAC) help the direct insurance companies to determine the optimal decision process of the reinsurance method and the optimal retention level. Return on Risk-Adjusted Capital (RORAC), defined as (Walhin, 2003):

$$
\text { RORAC }=\frac{\text { Income }}{\text { RISK-Adjusted Capital }}=\frac{E(\text { Profit })}{\text { RAC }}
$$

Where: $\quad \mathrm{RAC}=\mathrm{CTE}_{\alpha^{-}} \mathrm{P}$

And,

$$
\begin{aligned}
& \text { Profit }=\mathrm{P}-\mathrm{S}-\left(\mathrm{P}^{\mathrm{Re}}-\mathrm{S}^{\mathrm{Re}}\right) \\
& \text { Expected profit }=\mathrm{E}(\text { profit })=\mathrm{P}-\mathrm{ES}-\left(\mathrm{P}^{\mathrm{Re}}-\mathrm{E}\left(\mathrm{S}^{\mathrm{Re}}\right)\right)
\end{aligned}
$$

P: premium charged by the insurer (excluding administrative expenses and taxes).

S: random aggregate loss for the insurer.

$\mathrm{P}^{\mathrm{Re}}$ : premium charged by the reinsurer (including administrative expenses).

$\mathrm{S}^{\mathrm{Re}}$ : random aggregate loss for the reinsurer. 


\section{6- Data analysis and the applied study}

- The study will use real life data from the leading Egyptian insurance companies (Misr Insurance Company), in the non-life insurance type (Engineering).

- The study will use EasyFit Programme for fitting the frequency and severity distributions of claims. Also, R-statistical program "actuar package" for calculate Value-at-Risk (VaR) and Conditional-TailExpectation (CTE) of aggregate claim amount distribution.

\section{6-1 optimal Engineering reinsurance}

We will apply different proportional reinsurance programs on this portfolio to find out which is the optimal program for the insurer.

\section{6-1-1 No reinsurance Program:}

The study assumed The distribution of the Engineering Insurance claim numbers $\mathrm{N}$ is poisson with parameter $\lambda=0.094$.

The distribution of the Engineering cliam amounts, $\mathrm{X}$ is LogGamma Distribution with parameters $\alpha=51.8, \beta=0.267, \mathrm{E}(\mathrm{X})$ $=9.9096 \mathrm{E}+6, \quad \operatorname{Var}(\mathrm{X})=1.6063 \mathrm{E}+17$.

Figure (1) shown bleow down cdf of aggregate claim amount distribution of no-reinsurance Program.

\section{6-1-2 Quota Share reinsurance with proportion retention $\alpha_{\mathrm{i}}$ $40 \%$.}

The study assumed the frequency distribution is poisson with parameter $\lambda=0.094$, the severity distribution is Log-Gamma Distribution with parameters $\alpha=45.2, \beta=0.286 . \mathrm{E}(\mathrm{N})=\operatorname{Var}(\mathrm{N})=$ $0.094, \mathrm{E}(\mathrm{X})=4.1162 \mathrm{E}+6, \operatorname{var}(\mathrm{x})=4.6758 \mathrm{E}+16$.

Figure (2) shown bleow down cdf of aggregate claim amount distribution of Quota Share reinsurance with proportion retention ai $40 \%$ Program. 


\section{6-1-3 Quota Share reinsurance with proportion retention $\alpha_{\mathrm{i}}$ $50 \%$.}

The study assumed the frequency distribution is poisson with parameter $\lambda=0.094$, the severity distribution is LogGamma Distribution with parameters $\alpha=46.7, \beta=0.28, \mathrm{E}(\mathrm{N})=$ $\operatorname{Var}(\mathrm{N})=0.094, \mathrm{E}(\mathrm{X})=5.0951 \mathrm{E}+6, \operatorname{var}(\mathrm{x})=6.2244 \mathrm{E}+16$.

Figure (3) shown bleow down cdf of aggregate claim amount distribution of Quota Share reinsurance with proportion retention ai 50\% Program.

\section{6-1-4 Quota Share reinsurance with proportion retention $\alpha_{\mathrm{i}}$ $60 \%$.}

The study assumed the frequency distribution is poisson with

parameter $\quad \lambda=0.094$, the severity distribution is Log-Gamma Distribution with parameters $\alpha=48.029, \beta=0.27761$, $\mathrm{E}(\mathrm{N})=\operatorname{Var}(\mathrm{N})=0.094, \mathrm{E}(\mathrm{X})=6.0672 \mathrm{E}+6, \operatorname{var}(\mathrm{x})=7.9219 \mathrm{E}+16$.

Figure (4) shown bleow down cdf of aggregate claim amount distribution of Quota Share reinsurance with proportion retention $\alpha_{\mathrm{i}} 60 \%$ Program.

\section{6-1-5 Variable Quota Share reinsurance Program}

Insured retention different percentages depending on the limit $-50 \%$ of $20 \mathrm{M}$ limit, $40 \%$ of $30 \mathrm{M}$ limit, $30 \%$ of $40 \mathrm{M}$ limit, $20 \%$ of $50 \mathrm{M}$ limit, $0 \%$ of more than $50 \mathrm{M}$.

The study assumed the frequency distribution is poisson with parameter $\lambda=0.094$, the severity distribution is Log-Gamma Distribution with parameters $\alpha=62.429, \beta=0.2069, \mathrm{E}(\mathrm{N})=\operatorname{Var}(\mathrm{N})=0.094$, $\mathrm{E}(\mathrm{X})=1.9377 \mathrm{E}+6, \operatorname{var}(\mathrm{x})=3.0335 \mathrm{E} 14$. 
Figure (5) shown bleow down cdf of aggregate claim amount distribution of Variable quota share reinsurance Program.

\section{6-1-6 Surplus reinsurance Program}

The study assumed retention $=50 \mathrm{M}$, underwriting capacity $=250 \mathrm{M}$, reinsurance capacity $=200 \mathrm{M}=5$ Lines. Also we assumed the frequency distribution is poisson with parameter $\lambda=$ 0.094, The severity distribution is Gamma (3P) Distribution with parameters $\alpha=0.48, \beta=3.5738 \mathrm{E}+6$ and $\gamma=28130, \mathrm{E}(\mathrm{N})=\operatorname{Var}(\mathrm{N})=0.094$, $\mathrm{E}(\mathrm{X})=1.7386 \mathrm{E}+6, \operatorname{var}(\mathrm{x})=6.1128 \mathrm{E}+12$.

Figure (6) shown bleow down cdf of aggregate claim amount distribution of surplus reinsurance Program.

\section{6-1-7 Quota share and surplus}

Quota share with retention $50 \%$ and surplus with one retention (Average of Sum Insured) $7.8 \mathrm{M}$ for all policies.

The study assumed the frequency distribution is poisson with parameter $\lambda=0.094$, and the severity distribution is Lognormal (3P) Distribution with parameters $\sigma=1.6896, \mu=$ 12.708 and $\gamma=8888.5, \quad \mathrm{E}(\mathrm{N})=\operatorname{Var}(\mathrm{N})=0.094, \quad \mathrm{E}(\mathrm{X})=$ $1.3855 \mathrm{E}+6, \operatorname{var}(\mathrm{x})=3.1017 \mathrm{E}+13$.

Figure (7) shown bleow down cdf of aggregate claim amount distribution of of quota share with retention $50 \%$ and surplus reinsurance Program. 


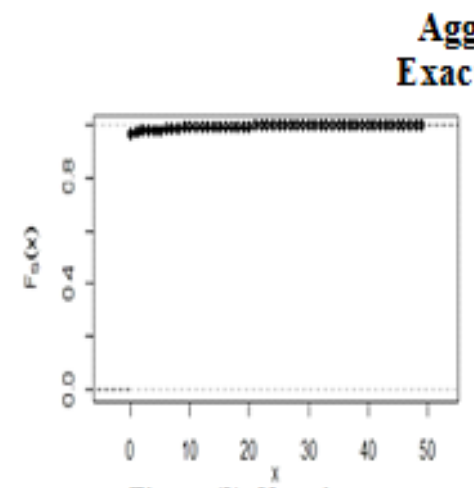

Figure (1): No reinsurance

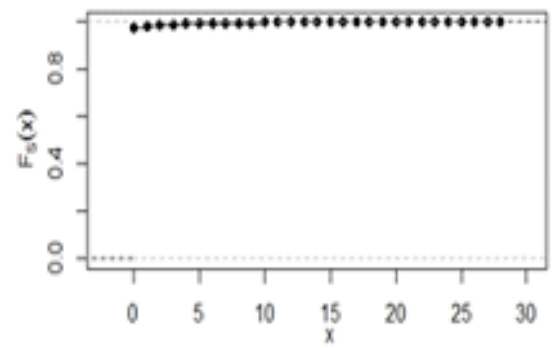

Figure (3): Quota Share reinsurance with retention $\mathbf{5 0} \%$

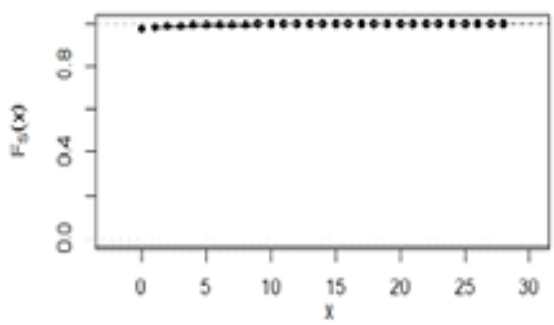

Figure (5): Variable Quota Share reinsurance

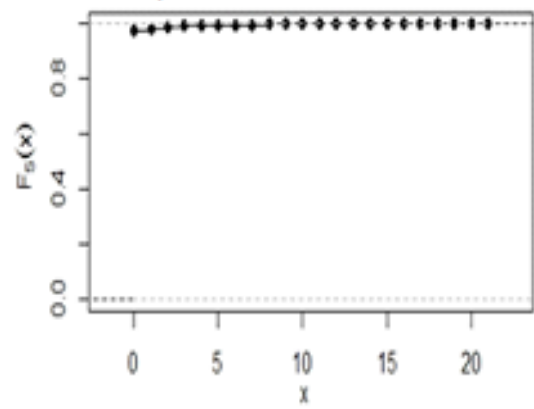

Figure (2): Quota Share reinsurance with retention $40 \%$

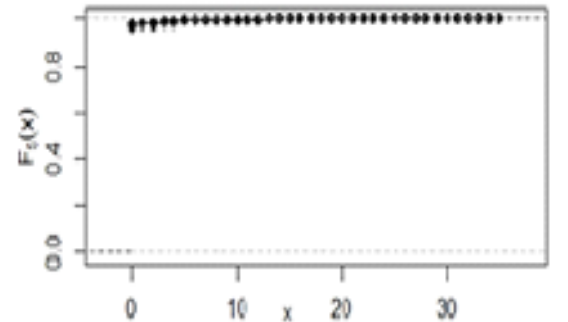

Figure (4): Quota Share reinsurance with retention $60 \%$

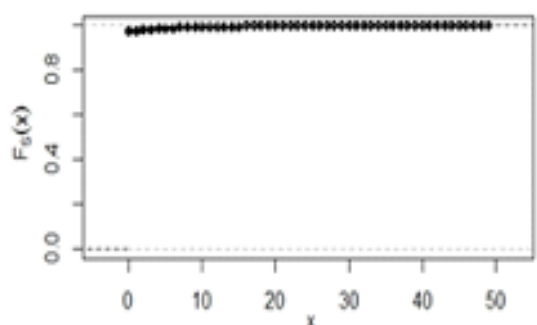

Figure (6): Surplus reinsurance

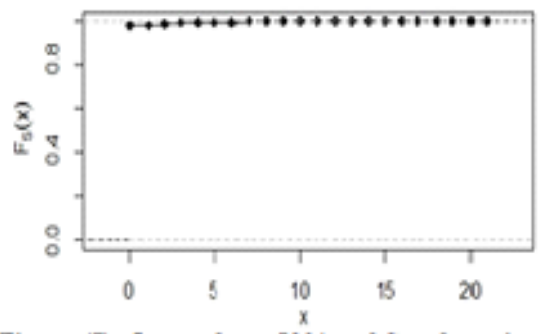

Figure (7): Quota share 50\% and Surplus reinsurance 


\section{7- Results}

Table (1) and Figure (1) sumarize the results of the study:

\begin{tabular}{|c|c|c|c|c|c|c|}
\hline & $\begin{array}{l}\text { Mean of } \\
\text { aggregate } \\
\text { claims }\end{array}$ & $\begin{array}{l}\text { Variance } \\
\text { of } \\
\text { aggregate } \\
\text { claims }\end{array}$ & $\begin{array}{l}\text { Standard } \\
\text { deviation of } \\
\text { aggregate } \\
\text { claims }\end{array}$ & $\begin{array}{l}\text { Value at } \\
\text { Risk } \\
\text { VaR(0.99) }\end{array}$ & $\begin{array}{l}\text { Conditional } \\
\text { Tail } \\
\text { Expectation } \\
\text { CTE(0.99) }\end{array}$ & $\begin{array}{l}\text { RORAC } \\
(0.99)\end{array}$ \\
\hline $\begin{array}{l}\text { No } \\
\text { reinsurance }\end{array}$ & 931502 & $\begin{array}{c}1.51 \mathrm{E}+ \\
16\end{array}$ & $\begin{array}{c}1.23 \mathrm{E}+0 \\
8\end{array}$ & 7 & 12.98 & $3.43 \%$ \\
\hline $\begin{array}{l}\text { Quota } \\
\text { Share 40\% }\end{array}$ & 386923 & $\begin{array}{c}4.39 \mathrm{E}+ \\
15\end{array}$ & $\begin{array}{c}6628468 \\
4\end{array}$ & 3 & 5.49 & $5.14 \%$ \\
\hline $\begin{array}{l}\text { Quota } \\
\text { Share 50\% }\end{array}$ & 478939 & $\begin{array}{c}5.85 \mathrm{E}+ \\
15 \\
\end{array}$ & $\begin{array}{c}7647545 \\
9 \\
\end{array}$ & 4 & 7.11 & $3.97 \%$ \\
\hline $\begin{array}{l}\text { Quota } \\
\text { Share 60\% }\end{array}$ & 570317 & $\begin{array}{c}7.44 \mathrm{E}+ \\
15 \\
\end{array}$ & $\begin{array}{c}8627355 \\
2 \\
\end{array}$ & 5 & 8.81 & $3.69 \%$ \\
\hline $\begin{array}{l}\text { Variable } \\
\text { Quota } \\
\text { Share } \\
\end{array}$ & 182144 & $\begin{array}{c}2.82 \mathrm{E}+ \\
13 \\
\end{array}$ & 5306784 & 3 & 5.45 & $3.94 \%$ \\
\hline $\begin{array}{l}\text { Surplus } \\
\text { reinsurance }\end{array}$ & 163428 & $\begin{array}{c}2.90 \mathrm{E}+ \\
11 \\
\end{array}$ & 538950 & 5 & 9.33 & $3.65 \%$ \\
\hline $\begin{array}{l}\text { Quota } \\
\text { share and } \\
\text { surplus }\end{array}$ & 130237 & $\begin{array}{c}2.74 \mathrm{E}+ \\
12\end{array}$ & 1653830 & 2 & 4.14 & $5.02 \%$ \\
\hline
\end{tabular}

\section{OPTIMAL ENGINEERING REINSURANCE METHODS USING RORAC}

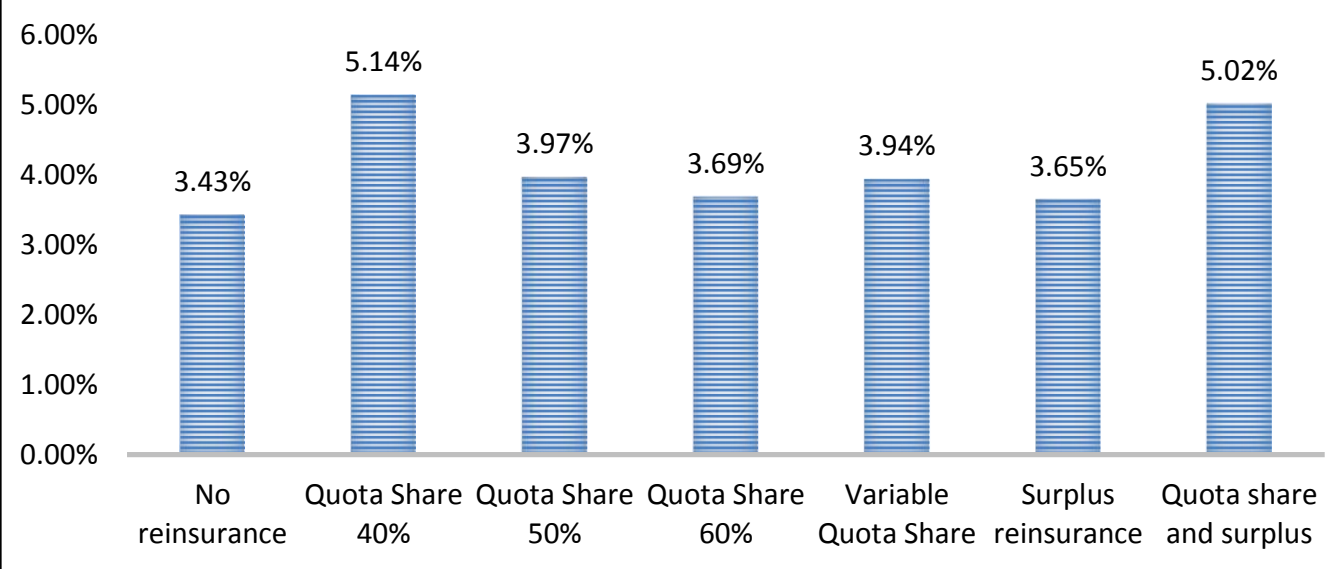

Figure (1) 


\section{Summary and Conclusion}

The study analyzed properties of types of proportional reinsurance covers (such as quota share reinsurance, variable quota share reinsurance, surplus reinsurance and quota share with surplus reinsurance). Also, assessed the impact of proportional reinsurance on the Egyptian insurance Market. we confined our analysis about the optimal reinsurance strategy with applied on the leading Egyptian insurance company "Misr Insurance Company".

The study used risk measures, the Value at Risk (VaR) and Conditional Tail Expectation (CTE) of aggregate claims distributions, which used among banks, insurance companies and other financial institutions for quantifying risk. Recently, these risk measures have been used to the determination of optimal reinsurance. This study Estimated optimal reinsurance by maximize the return on risk-adjusted capital of the retained risk (RORAC).

As table (1) and figure (1) shown the Optimal Engineering reinsurance method is Quota Share with retention level 40\%. This method of reinsurance will maximize the return on risk adjusted capital of the retained risk (RORAC) 5.14\%.

The numerical application has confirmed that quota share reinsurance is optimal when compared to surplus reinsurance method.

Based on the results from this study, the Egyptian Financial Supervisory Authority (EFSA) must reestablished the Egyptian Reinsurance Company to underwriting and become again the largest share of the reinsurance operations both in Egypt and the Arab world 


\section{References}

1. Artzner, P., Delbaen, F., \& Eber , J.-M. (1999). Coherent Measures of Risk. Mathematical Finance, 9, 203-228.

2. Balbás, A., Balbás, B., \& Heras, A. (2009). Optimal reinsurance with general risk measures. Insurance: Mathematics and Economics, 44., 374-384.

3. Balbás, A., Balbás, B., Balbás, R., \& Heras, A. (2015). Optimal reinsurance under risk and uncertainty. Insurance: Mathematics and Economics, 60., 61-74.

4. CAI, J., \& TAN, K. (2007). Optimal retention for a stop-loss reinsurance under the VaR and CTE riskmeasures. Astin Bull., 37(1), 93-112.

5. Cai, J., Tan, K. S., Weng, C., \& Zhang, Y. (2008). Optimal reinsurance under $\mathrm{VaR}$ and $\mathrm{CTE}$ risk measures. Insurance Math. Econom., 43., 185-196.

6. DeFinetti, B. (1940). Il Problema Dei Pieni. Istituto italiano degli attuari.

7. Denuit, M., Dhaene, J., Goovaerts, M., \& Kaas, R. (2005). Actuarial Theory for Dependent Risks: Measures, Orders and Models. John Wiley \& Sons.

8. Dickson, D. C., \& Waters, H. (2006). Optimal dynamic reinsurance. ASTIN Bulletin, 36(2), 415-432.

9. Dutang, C., Goulet, V., \& Pigeon, M. (2008). An R package for actuarial science. Journal of Statistical Software.

10.Egyptian Financial Supervisory Authority (EFSA), (2017). Annual Insurance Market Report 2017.

11.El-bolkiny, M. T. (2000). A Review on Statistical Models in Actuarial Sciences. Unpublished lecture notes. faculty of Commerce. Mansoura University. Egypt.

12.Gerber, H. U. (1979). Introduction to Mathematical Risk Theory. Richard d Irwin. 
13.Gorge, G. (2016). Insurance Risk Management and Reinsurance. Lulu Press.

14.Gray, R. J., \& Susan, P. M. (2012). Risk Modelling in General Insurance From Principles to Practice. Cambridge University Press.

15.Hardy, M. R. (2006). An Introduction to risk Measures for Actuarial Applications. USA: Education and Examination Committee of the Socity of Acturies C-25-07, Casualty Actuarial Society and the Society of Actuaries.

16.HÜRLIMANN, W. (2010). Case study on the optimality of some reinsurance contracts. Bulletin of the Swiss Association of Actuaries, 2, 71-91.

17.Kaas, R., Goovaerts, M., Dhaene, J., \& Denuit, M. (2008). Modern Acturial Risk Theory Using R. Springer, 2th Edition.

18.Karageyik, B. B., \& Şahin, Ş. (2017). Determination of the Optimal Retention Level Based on Different Measures. Risk Financial Management., 10(1).

19.Karanovsky, B. (2016). Actuarial Pricing of Non-Proportional Reinsurance Treaties Using R. AV Akademikerverlag.

20.Klugman, S. A., Panjer, H., \& Willmot , G. E. (2012). Loss Models: From Data to Decisions. Wiley; 4th edition.

21.Lampert, I., \& Walhin, J. (2005). on the optimality of propotional reinsurance. Scandinavian Actuarial Journal, 3, 225-239.

22.Parodi, P. (2015). Pricing In General Insurance. CRC Press. Taylor \& Francis Group, LLC.

23.Pohl, S., \& Iranya, J. (2018). The ABC Of Reinsurance. VVWVerlag Versicherungs.

24.Reinarz, R. C., Schloss, J. O., Patrik, G. S., Kensicki, P. R., \& Elliott, M. W. (1990). Reinsurance Practices. Insurance Institute of America. 
25.SwissRe. (2002). An Introduction to reinsurance. Swiss Reinsurance Company.

26. Walhin, J.-F. (2003). On the Optimality of Multiline Excess of Loss covers. CAS 2003 Seminar on Reinsurance.

27.Walhin, J.-F., \& Glineur, F. (2006). De Finetti's retention problem for proportional reinsurance revisited. German Actuarial Bulletin, Vol. 28, 451-462.

28. Waters, H. R. (1979). Excess of loss reinsurance limits. Scandinavian Actuarial Journal, (1), 37-43.

29. WATERS, H., (1983). Some mathematical aspects of reinsurance. Insurance Math. Econom., 2, 17-26.

30.Yuen, K. C., Liang , Z., \& Zhou, M. (2015). Optimal proportional reinsurance with common shock dependence. Insurance: Mathematics and Economics. Volume 64., 1-13. 